\title{
The Improvement Of The Guidance And Counselling Teachers Or Counsellors' Understanding On The Five Focuses Of Individual Counselling Service And Their Application
}

\author{
$\operatorname{Yarmis}^{\mathrm{a}}$ \\ ${ }^{a}$ Universitas Negeri Padang, Padang, Indonesia \\ Corresponding e-mail: yarmis@ konselor.org
}

\begin{abstract}
Understanding and applying the five focuses of individual counselling service are the essential parts in increasing the quality of the students' daily life regarded as the goal of guidance and counselling service at school. Unfortunately, there are still a number of Guidance and Counselling teachers ignoring the five focuses of the service in carrying out individual counselling. They seem to neglect the fact that individual counselling is the key point (the heart) of Guidance and Counselling service. To deal with the problem, it is viewed necessary to increase the teachers or the counsellors' understanding on the five focuses of the service and train them to apply the points. There were 30 Guidance and Counselling teachers taking part in the program in Kota Solok. It consists of presentation, discussion, and practice sessions. In order to reveal the outcomes of the activity, evaluation on the process and the results was conducted. In general, it is revealed that the Guidance and Counselling teachers have good understanding on the five focuses of individual counselling service. Related to the implementation of the service, the teachers said that it could be categorized as adequate. Based on the results of the research, it is recommended to the Guidance and Counselling teachers to continuously conduct the five focuses of individual counselling service at school, and to take parts in any trainings related to the implementation of the individual counselling held by official organizations or universities.
\end{abstract}

Keywords: understanding and applying, five focuses of individual counselling service

\section{INTRODUCTION}

Increasing the Guidance and Counselling teachers or counsellors' understanding in assisting the students to develop their potential is very important. As the main performer of Guidance and Counselling service at school, the counsellors are expected to show their high concern on the issues that potentially lead students to an ineffective daily life either in or out of school. Until now, in Guidance and Counselling service, especially in individual counselling, the students tend to meet the counsellors for different reasons. Some of them come based on their strong willingness to see the counsellors, and discuss their problems (selfreferral); some come as it is recommended by others; and some even might be forced or encouraged by others (Prayitno; 2012).

Guidance and Counseling teachers or counselors do not seem to be too concerned about the arrival of the students they service. What needs to be noted is that students are individuals who come to a counselor with various reasons based on the development and problems they are experiencing.
The problems might be related to the changes and development of any sectors in their life such as in information and technology that could affect the students either positively or negatively. Positive effects might occur when the students make use of the information and technology to search for learning materials, or to build friendship, find a place/ location, or monitor the development in the world. Meanwhile the negative effects could rise when the students are too captivated with the information and technology they use without considering the time and goals. The use of unfavorable information and technology is an example of an ineffective daily life of the students. The development of information and technology needs to be responded in the right way so that the students could get benefits from. They are encouraged to do useful activities that could become the characteristic of their effective life.

Individual counselling which is conducted based on the five focuses of the service are expected to help the students to achieve an effective daily life. This research then would define individual counselling, five focuses of individual counselling 
service, the implementation of the five focuses of individual counselling service, and the importance to commit five focuses of individual counselling service.

\section{REVIEW OF THE RELATED LITERATURES}

\subsection{Individual Counseling Service}

Individual counselling service is one of services provided in Guidance and Counselling program. It is a face-to-face interaction between a client and a counsellor which is carried out on the basis of voluntary, openness and confidentiality principles. The problems discussed are likely to be related to individual, social, academic, and career matters. The clients might come based on their own willingness (self-referral) or others' recommendation (other referral).

\subsection{Five Focuses of Individual Counseling Service}

Individual counseling service is one of Guidance and Counseling services whose operational procedure needs to be mastered and understood by every Guidance and Counseling teacher or counselor. The five focuses of the service comprise of knowledge and attitude toward clients, service goals, service setting, service technique, and evaluation on the service outcomes [1]. The five points are intended to provide a more precise and effective service to the clients.

\subsubsection{Focus 1: Knowledge and Attitude toward Clients}

Knowledge and attitude toward the clients could be defined as a counselor's insight, knowledge, and understanding on a client with which he/she shows certain attitude and acceptance to the client. The client is a unique individual who could be seen from his/her physiological and psychological aspects. Having extensive insight and knowledge about the uniqueness of the client could help the counselor in facilitating the client to develop. As a client is an individual who has a variety of uniqueness and privileges, the perception owned by a counselor about a client then might be varied. Uniqueness is a force in an individual that must be empowered (Reza M.Syarif: 2005).

The attitude of the counselor's toward the client is described as a person who; (a) has honor, (b) is dynamic, and (c) is responsible (Anthony Yeo, 1994). Furthermore, the counselor develops an understanding about clients, clients' reactions toward counseling, reluctant clients, and introvert clients. According to Prayitno (2010), to work with a client, the counselor should perceive that the client is an individual who individually has; (A) dignity, (b) nature, (c) nurture, (d) self condition, and (e) motivation.

\subsubsection{Focus II : Goals of the Individual Counseling Service}

The individual counseling service conducted should be client-oriented. In other words, the counselor has greater concern with his/ her clients' purpose instead of his/her own intention. The counselor is responsible for encouraging his/her clients to develop their potential, strengthens, and autonomy, and to manage or direct themselves to achieve formulated goals. The goals of individual counseling service are to achieve: (1) effective daily living (after the counseling done, the clients are expected to be able to run an effective daily life and gives benefits for themselves, family, society, and nation, and shows their devotion to the God, and (2) good relationship with others (the clients are able to build harmonious relationship with others in their family, school, office, community and so on [2]. In addition, [1] states that individual counseling service is intended to: (a) promote the clients' effective daily life which is proper to their existence as an individual and as a part of a system by maximizing their potential, (b) overcome the problems aggravating the clients' effective daily life (clear away every obstacle hampering the clients to achieve an effective daily life either as an individual or as a part of a system, (c) activate learning energy (make use of the clients' potential to help them achieve an effective daily life), (d) achieve the goals of education, dan (e) synchronize the now and hereafter life by improving the clients' devotion to Allah, increasing their responsibility toward themselves and others, and improving their obedience to the applicable regulations and laws.

\subsubsection{Focus III: Service Setting of the Individual Counseling Service}

Service setting of the individual counseling service is related to where, when, to whom and how the service is conducted. Ideally, individual counseling service is committed in a special room which is well-designed to provide warmth and friendliness, and to make the clients feel relaxed. This is in line to what is proposed by [3] a welldesigned counselling room will have a warm and friendly atmosphere that could help the clients feel at ease. In addition to being warm, pleasant, 
welcoming, and comfortable, the room must be set up so that it is suitable for serious profesional work.

According to [1], there are several aspects that should be taken into account in conducting individual counseling service including: (a) physical space, (b) atmosphere of the service, (c) relationship between the counselor and the client, (d) intervention, and (e) freedom of movement. This means that the service provider should pay attention to the physical condition of the room (indoor / outdoor), including seating, air circulation, and lighting. The room also has to be soundproof. In addition, the service provider should also consider the atmosphere around the place of the service. It has to be comfortable, safe, and able to motivate the clients to discuss the problem and continue the process to realize the principles of the counseling. Likewise, the relationship that takes place in individual counseling service should be full of acknowledgement, acceptance, affection, tenderness, and appreciation. The use of data, media, and literature might also be useful in individual counseling service. Furthermore, the service providers should also pay attention to the service setting that could provide freedom of movement and a variety of alternatives for the implementation of dynamic service.

Before conducting individual counseling, it is important for the counselor to know the client, arrange the meeting, provide facilities needed, and prepare administration stuff.

\subsubsection{Focus IV: Operational Technique of the Individual Counseling Service}

The operational technique of individual counseling service is a service practice that refers to the Standard of Operational Procedure (SOP) from the beginning to the end of the service. Prayitno, et al (2016) affirmed the importance of managing the implementation of each type of supporting services and activities by implementing the SOP of each.

Individual counseling service is carried out by considering several phases or stages. [4] states that the phases include: building a counseling relationship, assessing specific needs of the counseling, designing and implementing interventions, and conducting evaluation and closure. Meanwhile Prayitno (2004) affirms that there are five phases undertaken in individual counseling service, namely; (1) introduction stage, (2) investigation stage, (3) interpretation stage, (4) intervention stage, and (5) assessment (inspection) stage.

In the introduction stage, the counselor accepts the client as he/she is, establishes rapport with the client, and builds client perceptions. In the investigation stage, the counselor explores the client's problems through self and other related problems disclosure. The counselor will use appropriate techniques to identify the client's problems such as by using open questions, minimum encouragement, eye contact, psychological contact, $3 \mathrm{M}$ and so on. In this process, the counselor interprets the client's problems and everything that exerts influences upon them in the form of problem analysis and diagnosis.

In the interpretation stage, the counselor should have a deep understanding on the client's problems, although the interpretation of all statements made by the client and the disclosure of the problem will be taking place until the counseling ends. Furthermore, the counselor conducts intervention stage by considering the tendency of the client selfdevelopment, the solution, and the formation of new behaviors.

In the intervention stage, the counselor activates the various strengths that exist in and around the client to realize an effective daily life. Finally, the counselor does an assessment to find out the results obtained from the counseling held (called the assessment stage). The assessment on the individual counseling service conducted could be done by using laiseg format (immediate assessment), and through direct or oral questions.

The implementation of individual counseling is different from other forms of interaction in counseling services in term of emotional contacts, focus of conversation, and goals to be achieved.[4] puts the difference to the following statement:

"What distinguishes individual counseling from other forms of interaction is; (1) the close emotional contact between the student and the professional school counselor, (2) the focus is on the student's problem or concern, and (3) the goal is to help the student make positive changes is coping, in adapting, or in specific behaviors that are problematic."

Erford's opinion above implies that individual counseling is an emotional contact between a client and a counselor intended to help the client to make positive changes in term of coping, adaptation and particular behaviors which are regarded as the problems.

\subsubsection{Focus $V$ : Evaluation on the Outcomes of Individual Counseling Service}

Assessment on the outcomes of the individual counseling service is intended to produce something that significantly supports the client's selfdevelopment. The success of an individual counseling service supports the realization of an 
Effective Everyday Life and / or handling the interfered Effective Everyday Life of the client being served [1].

The success of an individual counseling service can be identified from the results of the assessment conducted. There are three kinds of assessment that need to be carried out on the outcomes of the individual counseling service, namely: immediate assessment, short-term assessment and long-term assessment (Prayitno 2012). Immediate assessment is immediately carried out at the end of each service session, while short-term assessment is committed when the client is in post-service period. It is done for one week to one month. Furthermore, long-term assessment is carried out after several months. The assessment is focused on improving the client's understanding on reference, competence, effort, feeling, and sincerity [1].

Reference is something that a client can follow to behave in a new way so that there is a change from an Interfered Effective Everyday Life to an Effective Everyday Life. Reference means any matters needed by the client to solve his/her problem. Reference can be used wherever the client's effective life is directed. Competence is about what skills the client needs to have to make a change from an Interfered Effective Everyday Life to an Effective Everyday Life, or to run an effective daily life. Competence also could be defined as something that the client needs to master to deal with the problems. Efforts can involve the plan of activities or real actions that a client needs to make for the realization of the change from an Interfered Effective Everyday Life to an Effective Everyday Life. Feelings are related to the mood felt by the client, such as being relief, relaxed and free from problems. Meanwhile seriousness is concerned with the client's willingness, persistence, and desire to change him/herself in doing various efforts required for realizing the change from an Interfered Effective Everyday Life to an Effective Everyday Life.

\subsection{The Importance To Increase The Guidance And Counselling Teachers Or Counsellors' Understanding On The Five Focuses of Individual Counselling Service And Their Implementation}

The improvement of the Guidance and Counselling teachers or counsellors' understanding on the five focuses of individual counselling service and their implementation is necessary as the target of the service is teenage students. The description of the achievement of the teenagers' developmental tasks is varied. One of them could be seen from the results of the research conducted by [5] revealing that the adolescents' development task in terms of building new and more mature relationships with peers of the same or different gender in general is in adequate category, while that in term of committing social roles in accordance with gender in general is also in adequate category.

As the main performers of Guidance and Counseling service at school, the Guidance and Counseling teachers or counselors are expected to show a high level of concern with issues that could lead students to an ineffectiveness life both in and out of school. Students are individuals who are studying in formal educational institutions and struggling for improving their insight, knowledge, understanding, skills, values and attitudes through learning activities. Students are expected to succeed in carrying out their educational and developmental tasks. The tasks of the student development as a teenager include the following capabilities, namely; (1) accept their physical condition, (2) accept and understand the role of genre (3) foster good relationships with members of different groups, (4) achieve emotional independence, (5) achieve economic independence, (6) ) develop intellectual concepts and skills needed to take a role as a community member, (7) understand and internalize the values of adults and parents, (8) develop social responsibility required to enter the adult world, (9) prepare to enter marriage, and (10) understand and prepare for the responsibilities of family life (Hurlock, 2008).

The service given by the Guidance and Counseling teachers or counselors is oriented to the students' development and problems [6]. Facilitating the students to get an effective daily life is the goal of guidance and counseling service at schools that is characterized by an efficient life for him/herself, family, community, nation, and God [2]

\subsection{The Implementation Of The Five Focuses of Individual Counseling Service}

The implementation of the five focuses of individual counseling service can be described as follows: 


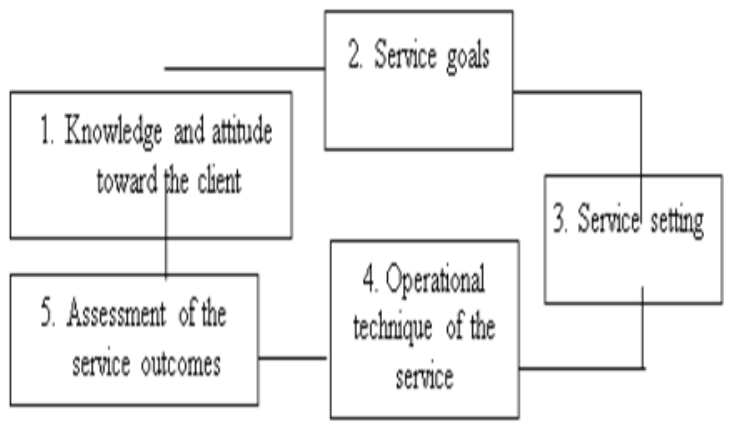

Figure 1. the implementation of the five focuses of individual counseling service

The above figure describes that the implementation of the five focuses of individual counseling service is intended to give full attention to the client before, during, and after the service is given. Such knowledge and understanding would place the client as a unique and prestigious individual who has potential to be developed through educative intervention. As the service provider, the counselors highly appreciate the client's expectations and they do not work based on their own individual needs. To obtain optimal service outcomes, the Guidance and Counseling teachers should be more concerned about where and when the service is delivered, and the facilities needed.

The counselors will give the service officially by using relevant techniques and theories that could enrich the discussion of the service. During the service, the counselors would assess the client about his/her involvement and cooperation in handling the problems. Similarly, after the service ends, the counselors will conduct an evaluation to find out the success of the service given and to obtain information about the client's understanding on the service he or she has participated on.

\section{METHOD OF THE ACTIVITIES}

The individual counseling service is conducted by applying presentation, question and answer (discussion), and exercise methods in October 2016.

a) The presentation method is used to expose the material theoretically. The use of this method could help the participants in understanding the materials presented.

b) Question and answer (discussion) method is used in order to enrich the material presented so that it can facilitate the participants to take parts in the next exercise.

c) The exercise method is used to apply the material that has been presented verbally so that the participants can carry out the steps in working with the object of the service.

\section{FINDINGS AND DISCUSSION}

\subsection{Findings}

The effort to improve the Guidance and Counseling teachers or counselors' understanding on the five focuses of individual counseling service and their implementation was successfully carried out. The activities went well. Generally, the results are presented in the following table:

Table 1. The improvement of the Guidance and Counseling teachers or counselors' understanding on the five focuses of individual counseling service and their implementation

\begin{tabular}{|r|c|l|l|c|l|}
\hline No & \multicolumn{2}{|c|}{ Sub-Variables } & \multicolumn{2}{|c|}{$\begin{array}{c}\text { Level of } \\
\text { Understanding }\end{array}$} & \multicolumn{2}{c|}{$\begin{array}{c}\text { Level of } \\
\text { Implementation }\end{array}$} \\
\cline { 3 - 6 } & & Before & After & Before & After \\
\hline 1 & $\begin{array}{c}\text { Knowledge and } \\
\text { attitude toward clients }\end{array}$ & Adequate & Very Good & Good & $\begin{array}{c}\text { Very } \\
\text { Good }\end{array}$ \\
\hline 2 & Service goals & Adequate & Good & Adequate & Good \\
\hline 3 & Service setting & Adequate & Very Good & Adequate & Good \\
\hline 4 & $\begin{array}{c}\text { Operational } \\
\text { technique of the service }\end{array}$ & Adequate & Very Good & Adequate & Good \\
\hline 5 & $\begin{array}{c}\text { Assessment on the } \\
\text { service outcomes }\end{array}$ & Adequate & Very Good & Adequate & Good \\
\hline
\end{tabular}

The above results illustrate that there is an increase in the mastery of the Guidance and Counseling teachers or counselors on the five focuses of individual counseling service and their implementation for each of the sub-variables discussed, namely knowledge and attitude toward clients, service goals, service setting, operational 
technique of the service, and assessment on the service outcomes.

\subsection{Discussion}

In general, the Guidance and Counseling teachers or counselors' understanding on the five focuses of individual counseling service and their implementation improves. Similarly, their skills, values and attitude on such service also increase. These results are revealed through evaluation on the process, and question and answer on the materials and exercises done. All participants listened actively and felt curious about the implementation of the individual counseling in terms of knowledge about the client, service goals, service setting, operational technique of the service, and assessment on the service outcomes. In face-to-face practice, the participants are provided with pictures of the implementation of the individual counseling.

The results of the training activities indicate that there is an increase in Guidance and Counseling teachers or counselors' understanding on the five focuses of individual counseling service and their implementation. Having an excellent understanding on such service would provide students with great opportunities for individual counseling service that help them to get self-understanding and solve their problems appropriately. Furthermore, improving the quality of the five focuses based individual counseling service would make the students feel more confident and think that the counselor is the one who needs to be visited to discuss their problems with. In addition, the improvement of the Guidance and Counseling teachers or counselors' understanding on the five focuses of individual counseling service and their implementation in a broader scope could enhance the students' perceptions toward the counselors in individual counseling service. The result of the research conducted by Dian Putri Rachmadhani (2016) in class IX of SMP Negeri 2 Kebumen shows that 58\% of the students perceived that the Guidance and Counseling teachers or counselors were in good category and $42 \%$ of them thought that the Guidance and Counseling teachers or counselors were in medium category.

\section{CONCLUSION}

Based on the results of the research, it is believed that giving trainings to enhance the counselors' knowledge, understanding and skills in conducting individual counseling especially that by applying the five focuses of the service is necessary.
Therefore, the counselors who have taken the training are demanded to carry out individual counseling service by applying the five focuses of the service, while those who have not yet participated in the training are suggested to participate in training organized by professional organization of Guidance and Counseling (called ABKIN or MGBK) in their own district/ area. Such trainings are expected to increase the quantity and quality of the service given by counselors in helping the students to overcome their problem.

\section{BIBLIOGRAPHY}

[1] Yarmis Syukur (2013). Pemahaman dan Penerapan, Permasalahan dan Arah Pengembangan Fokus Layanan Konseling Perorangan Guru BK atau Konselor (Studi di SMA Negeri Kota Padang). Disertasi. Program Pascasarjana Universitas Negeri Padang.

[2] Syofyan S. Willis (2009). Konseling Individual; Teori dan Praktek. Bandung: Alfabeta

[3] Geldard, David (1993). Basic Individual Counselling; A Training Manual for Counsellors (second edition). Prentice Hall of Australia Pty Ltd.

[4] Erford, Bradley T (2007). Transforming the School Counseling Profession. New Jersey 07458, Pearson Education,Inc, Upper Saddle River.

[5] Vivi Andriani (2014). Gambaran Tugas Perkembangan Remaja di Panti Asuhan kota Padang. Padang: FIP UNP (Skripsi; tidak diterbitkan).

[6] Prayitno \& Erman Amti (2004). Dasar-dasar Bimbingan dan Konseling. Jakarta: Depdikbud.

[7] Yeo, Anthony (1994).. Counselling; a Problem Solving Approach (Konseling; Suatu Pendekatan Pemecahan Masalah; Terjemahan). Published; Armour Publishing Ptc.Ltd.

[8] Prayitno (2004). Layanan Konseling Perorangan (Seri Layanan Konseling; L.5). Universitas Negeri Padang: Fakultas Ilmu Pendidikan.Jurusan Bimbingan dan Konseling.

[9] Dian Putri Rachmadhani (2016). Persepsi Peserta Didik terhadap Guru BK dalam Melaksanakan Layanan Konseling Perorangan Kelas IX SMP Negeri 2 Kebumen. UniversitasAhmad Dahlan;Psikopedagogia. 